\title{
Fejér vármegye közbiztonságtörténete 1688-1884
}

Fejér vármegye először 1009-ben található a korabeli dokumentumok között. Egyetlen városa Fehérvár (Alba Regia, Fehérvár, Istolni Belgrád, Stulweisenburg, Székesfehérvár) 1018 óta királyi, szakrális székhely, amely a Magyar Királyságban meghatározó, szerepet töltött be a török hódoltság kezdetéig, 1543-ig. Fejér vármegye megszervezésétöl kezdve királyi vármegyeként müködött, majd — a II. András által kiadott 1222-es Aranybullát követően - megkezdődött a nemesi vármegye és intézményrendszere fokozatos kialakulása, fejlődése.

A nemesi vármegye tehát a területén birtokkal rendelkező nemesek önkormányzattal bíró szervezete volt, de ugyanakkor a királyi hatalom gyakorlását is biztosította. A XV. századtól csökkent az ítélkezés szerepe, a legnagyobb földesurak megszerezték az önálló ítélkezés jogát. Bár a nemesi vármegye tekintélye csökkent, ám politikai befolyása 1848-ig töretlennek volt mondható, és később a dualizmus korában is mértékadónak számított az állami közigazgatás mellett. Főként a HABSBURG-uralom alatt nőtt meg a politikai befolyása, mert a rendi ellenállás védőbástyája volt.

A vármegyék 1520-tól több feladatot kaptak: törvények, rendeletek végrehajtása, önkormányzati igazságszolgáltatás, a jobbágyság feletti hatalom és adószedés. Ezt követően törvénybe foglalták azt is, hogy a királyság és a helytartóság törvénytelen rendeleteit nem kötelesek végrehajtani.

Fejér vármegye területe a megalakulásakor lényegében két földrajzi egységre tagolódott, amely kezdetben a Duna két oldalán helyezkedett el. ${ }^{1}$ Ezt a kettős helyzetet számolta fel, — a török hódoltság területét érintően - 1596. évi országgyülés, amely a Duna-Tisza közén elterülö Solti széket az 52. törvénycikkel Pest-Pilis vármegyéhez csatolta. ${ }^{2}$

Ebben az időben Fejér vármegyét két járásra osztották, a Vértesaljai és a Sárréti járásokra. ${ }^{3}$

A vármegye területén ebben az időben elsősorban magyarok, korábban a XI. században a területi autonómiát kapott besenyők (a Sárvíz mellékén), valamint a Fehérvárott külön kiváltságokat is élvező vallonok (latinok) és végül a XIII. században Perkátán, ${ }^{4}$ míg később a XIV. században Hantos környékére is kunok települtek, akik kapitánysággá szerveződtek. Az 1400-as évektől kezdődően Fehérváron és a Duna partján megjelentek a rácok települései is, sőt akkor már a királyi Magyarországon megjelentek a folyamatos mozgásban lévő cigányok is. A lakosságnak ez a sokszínüsége a vármegye történeténél mindig is jelen volt. ${ }^{5} \mathrm{~A}$ hadi utakkal összefüggésben, sőt a keresztes hadak mozgásával kapcsolatban, vagy a tatárjárás során, legtovább a törökellenes küzdelmek alkalmával, a hadak mozgásakor, vagy a cigányok letelepítésével összefüggésben a falvak lakossága, élete- testi épsége, tulajdona, terményei, termékei, de még a vásárok biztonsága is folyamatosan veszélyben voltak. A lakosság csak hosszabb-rövidebb ideig volt biztonságban a bünözéssel szemben. Mindezek a tények kihatással voltak a megye közrendjére, közbiztonságára, egyúttal pedig gyengítették a nemesi vármegye intézményrendszerének kiépülését és működését.

Fejér vármegye szervezeti felépítése lényegében megegyezett a többi vármegyével. Fejér vármegyét érintő minden fontos vármegye területén fekvő királyi városok önálló bíráskodási jogot kaptak, azonban a nemesség birtok- és egyéb pereiben nem ítélkezhettek.

Elterjedt gyakorlat volt, hogy a megyében birtokos mágnások, egyházi személyek — akiket sem hivataluk, sem lakóhelyük nem kötött szorosan a vármegyéhez — tiszttartójukat vagy teljes jogú meghatalmazottjukat küldték el a megyegyülésekre. A közgyülésen tárgyalt ügyek kiterjedtek a megye életének szinte egészére. Fontosságukat gyakoriságuk mutatta. Gyors döntést kívánó esetekben, amikor nem volt már idő vagy lehetőség a közgyülés összehívására, akkor azokat értesítették, akiket könnyen elértek, és ők döntöttek a tisztviselőkkel: részleges vagy kisgyülésen. A gyülés helyszínének, jellegének dátumának a rögzítése után a jegyzőkönyvek ismertetik a jelenlévők névsorát. Napirendi pontok szerint nem számozták meg az ügyeket. Elsőként a királyi vagy felsőbb hatóságoktól érkezett leiratokat ismertették. A velük kapcsolatos teendőket azonnal megvitatták, döntöttek és az intézkedéseket jegyzőkönyvezték. Minden közgyülés tárgyalta a megye „közrend - közbiztonsága - közbátorsága” helyzetét, de azt mindig követő jelleggel tették. A közgyülés küldte ki a tisztviselöit a legkülönbözőbb: adó, katonaügyek, határviták stb. intézésére. Megfogalmazta a követek utasításait, beszámoltatta öket, $s$ intézkedett tevékenységük pénzügyi finanszírozásáról is. Itt mutatták be a nemesi kiváltságleveleket. A közgyülések lefolytatásában megfigyelhető gyakorlat., hogy utoljára tárgyalták a birtokos nemesek közötti határviták kapcsán bejelentett eltiltásokat, $\mathrm{s}$ az ezekkel kapcsolatos ellentmondásokat.

A nemesi vármegye legfontosabb - a rendfenntartás irányításában is valamilyen formában résztvevő — tisztségviselői voltak: 
- Föispán (sempremus comes): A nemesi vármegye élén álló legfontosabb funkció, személyét a legnagyobb birtokkal rendelkező földesurak közül jelöli ki a király. A föispánt be kellett iktatni és hitellevélre kellett felesketni.

- Alispán (vice comes): a vármegyei közigazgatás feje 1950-ig. A 16. században vált a megye legfőbb választott tisztségviselőjévé, amikor az egyházi és a világi főurak helyett a megye nemessége vált a meghatározó réteggé. 1546-tól a vármegyék másodalispáni funkciót is szerveztek. A másodalispán a bíráskodásban helyettesítette az alispánt.

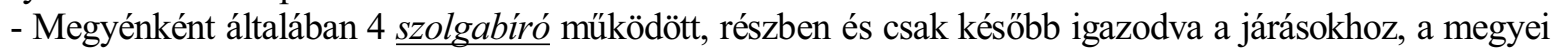
törvényszék tagjai voltak az ispánnal együtt, azonban, majd annak alárendeltjeként működtek. Intézkedéseikről jelentést készítettek az alispánnak. A járások kialakulásával és többszöri változtatásával kialakul járásonként a föszolgabíró és a néhány alszolgabíró intézménye is. A nemesi vármegyében a szolgabíró töltötte be a közigazgatás, az igazságszolgáltatás legfontosabb tisztségét, $\mathrm{s}$ általában felelt mindazért, ami a vármegyében történt. Ő rendelkezett a karhatalommal (hajdúkkal, darabontokkal, pandúrokkal és vármegyei huszárokkal), velük közösen vezette az általános helyszíni nyomozást, a mindenkor „elkésett helyszíni szemlét" is, sőt részt vett a bủnözők elleni cirkálásban. Erre mindig akkor került sor, ha a vármegyében romlott a közrend-közbiztonság helyzete.

- Notárius (jegyzö): fogadott és fizetett tisztségviselő volt, írásbeli és adminisztratív tevékenységet folytatott. Felelős volt az adminisztráció intézésének, feladata az írásbeliség végrehajtása és a megyei pecsét örzése lett. A tisztség Mária Terézia óta állandósult tisztség volt.

- Esküdtszék (jurati nobiles): kezdetben esküdt nemesek, akik a szolgabíró mellett a jogszolgáltatásban segítettek, később az igazgatási tevékenységben is részt vettek.

A vármegye kétféle jogszolgáltatási tevékenységet végzett. Egyrészt müködtette a vármegyei törvényszéket: az ítélőszéket, a sedriát, amely a nemesek büntető és polgári peres ügyeiben járt el, és amelynek ítélet kiszabási és végrehajtási pallosjoga volt. Ez a vármegye legrégebbi testületi fóruma, amely helyi szinten jogalkalmazási funkciót gyakorol. Első fokon a nemesek, másodfokon pedig a jobbágyok ügyeiben is ítélkezhetett. Kiszabhatta és végrehajthatta az ítéleteket. Másrészt a rendi különbségek figyelembevételével müködött az úriszék, amely a parasztok ügyeiben másodfokon ítélkezett, és amely a falusi bíróság feljebbviteli szerve volt.

A XV. századtól kezdve csökkent a vármegye ítélkezési szerepe, mert a legnagyobb földesurak megszerezték az önálló ítélkezés jogát, sőt a pallosjogot is. 1520-tól azonban egyre több feladatot kaptak a vármegyék törvények, rendeletek végrehajtása, önkormányzati igazságszolgáltatás, adószedés stb. tárgyában. 1526-tól (a Mohácsi csatavesztés után) a kormányzati központ Bécsbe kényszerült, a Fejér vármegyei föispán és a tisztikara azonban Győrben székelt, a vármegye magára maradt, ugyanakkor a helyi ügyek intézése tekintetében megerősödött autonómiája, amit egyfajta jogi autonómizmus is követett. A vármegye megmaradó ÉNY-i részét pedig ideiglenesen Veszprém és Komárom vármegyéhez csatolták. Az autonómiát jelentős mértékben erősítette azon 1545-ben létrejött törvény, amely lehetővé tette, hogy a vármegyék a királyi helyhatóság törvénytelen rendeleteit nem kötelesek végrehajtani. A nemesi vármegye tekintélye összességében csökkent ugyan, ám politikai befolyása 1848-ig töretlennek mondható. Főként a HABSBURG-uralom alatt nőtt meg a politikai befolyása, mert a rendi ellenállás védbástyája volt. ${ }^{6} \mathrm{Az}$ önkormányzatiság jegyében XVIII. században országszerte megyeházak, börtönök épültek.

\section{Fejér vármegye közbiztonsága.}

Már a nemesi vármegye tisztikara is a legfontosabb feladatai között tartotta számon a közbiztonság kezelését. A térség viharos történelmének a sodrában a közrend romlásáról azonban a vármegyei nemesség nem tehetett, az események megváltoztatták, sőt rendre károsan befolyásolták a vármegye, közrendvédelmi helyzetét és hosszú időre elnapolták a téma megnyugtató rendezését.

Fejér vármegye és a szomszédos vármegyék területe 1543 és 1688 közötti török uralom alatt állt. A török közigazgatás budai vilajetén belül, három szandzsákja fedte le a Kelet-Dunántúli térséget: a budai, a székesfehérvári, amely egyúttal nahie-nek (járás) is számított, és a simontornyai szandzsák. Fehérváron ebben az idöben fegyvergyár, fegyvertár, lőszerraktár, salétrombánya, börtön (átlagosan 70 magyar rabbal), magtár, mészárszék, élelmiszerraktár is müködött. ${ }^{7}$ A török közigazgatásra jellemző az volt, hogy Buda környékén igen erős volt, a végvárak között gyenge, a Duna-Tisza közét, pedig szinte teljesen magára hagyták. A területen közbiztonságról nem lehetett beszélni, emiatt ott kialakulhatott a parasztvármegye intézménye, amely - a törökök hallgatólagos beleegyezésével - elsősorban a közbiztonság javítására egymással szövetkező falvak védelmi szervezete volt. Az éves adóbehajtástól eltekintve a hódítók azért engedték, 
hogy az adózás eredménye minél nagyobb haszonnal záruljon a török tisztikar számára. ${ }^{8}$ A török hadak számára a térség katonai felvonulási területnek számított. ${ }^{9}$ Uralmuk idején és a háborúk alatt a vármegye falvai pusztulásnak indultak és elnéptelenedtek, a lakosságszám kb. 55 ezer före csökkent. Ezzel párhuzamosan a falvak lakóit 1650-től a HABSBURG szimpatizáns önkéntesek is folyamatosan zaklatták rablással, kifosztással és általában erőszakoskodásukkal. Fejér vármegye 1686-tól letiport, legázolt, fölégetett földekből álltt. ${ }^{10}$ Már ekkor is jellemző büncselekmények voltak: a rablás, az útonállás, a marha- és ló-tolvajlás, és általában az emberi élet elleni büncselekmények.

A vármegye területe 1688-ra a Solti szék leválása miatt jelentősen kisebbedett, gazdasági ereje csökkent. Az 1686-os kamarai összeírás szerint a megyében és egy városban, amelyet széthordtak és kifosztottak, Fehérvárt elhagyatva találják. A 65 faluból 25-ben laktak, 11-ben gyéren laktak (azaz 36 településen élt lakosság), 29 falu elhagyatott és mintegy 400 lakóház lakatlan volt. ${ }^{11}$ A lakosság 1683-tól a Dunántúli Közép-hegységben és a Sárvíz mocsaraiban húzódott meg. ${ }^{12}$ A lakosság a vallását tekintve is megosztottá vált. A közbiztonság megyeszerte teljesen hiányzott. A lakossági terheket csak fokozták a mintegy 30 ezer fös európai hadsereg fegyelmével, ellátásával és beszállásolásával kapcsolatos gondok. A HABSBURGok 1688 után folyamatosan, mintegy évszázadig folytatták a terület betelepítését, benépesítését. ${ }^{13}$ Fejér vármegye északi részének felszabadítására 1686-1688 között került sor, a déli területek pedig 1686 kora őszén váltak szabaddá.

A győztes szövetséges osztrák, német, bajor és lengyel csapatok 1688-1692 között Fehérváron és a vármegyében katonai közigazgatást vezettek be, amelynek parancsnokául báró AREYZAGA János ezredest nevezték ki, aki a legkeményebb eszközökkel próbálkozott a közrend fenntartására, ismét bevezette a város kapuinak éjjeli zárását, lovas- és gyalogos járörcsoportok portyázták a város és megye területét is. A megye közbiztonságának a javítására ezek az intézkedések azonban nem voltak elegendök.

A bécsi udvar Fejér vármegyét szerzett földterületnek minősítette. A földek újraelosztására 1691. december 9.-én létrehozták az „Újra-szerzeményi Bizottságot”. Ennek során azok jutottak nagyobb földbirtokhoz, akik a HABSBURG ház hüséges támogatói voltak. ${ }^{14}$

A katonai közigazgatást 1692. július 12.-én a felváltotta nemesi vármegye közigazgatása, ${ }^{15}$ amely viszszakapta az elvesztett jogintézményeit és hangsúlyozottan közigazgatási és rendvédelmi önkormányzatiságát is. A rendvédelmi igazgatási jogosítványa az önkormányzati jogok legfontosabb területét jelentette. A megye főispánjává az uralkodó kinevezte gróf EsZTERHÁZY Ferencet, visszaállították és megválasztották az alispánt, helyettesét és a főszolgabírót, továbbá nyolc nemest választottak szolgabírónak, valamint müködtették a katonai biztosi intézményt. Az uralkodó a nemesi vármegye régi jogainak visszaadását 1694. október 10.-én az új vármegyei pecsét adományozásával külön is elismerte. A megye kiváltságai szükebbek voltak, mint Fehérvár városé, amely 1703-ban I. Lipót császártól a „Diploma Leopoldinum” nevü dokumentummal visszakapta régi kiváltságait, alapjogait. Ezek között felsorolták a vámmentességet, a saját jogszolgáltatást, mint a bíró és az esküdtek, a polgári, büntető és vagyoni jogosítványokat, megerősítették a függetlenségét a nemesi vármegyétől, befogadási jogot kapott, lakóinak csak a királyi seregben kellett katonáskodniuk, szabad végrendelkezési és pecsételési jogot kapott. ${ }^{16} 1703$-tól miután Székesfehérvár városa a jogait visszakapta óriási fejlődésnek indult, amely egyben a vármegye fejlődése egyik motorjának is bizonyult. A mezöföldi fejlett növény- és állattenyésztés, a szőlő- és bortermelés, a város és a katonaság részére tartott gulyák, ménesek, kondák, nyájak tenyésztésével óriási kereskedelmi jövedelem keletkezett, amelyhez jelentős mértékben hozzájárult az évente öt alkalommal megrendezett székesfehérvári vásár is. A termelés és a kereskedelem jövedelmeiből a nagybirtokosok, valamint a város, a legjobban adózó virilisták és a mezővárosokban élő zsidóság gazdagodott elsősorban. A nemesi társadalom intézményrendszere jól müködött. A vármegye más privilégiumokkal együtt, önálló feladatául kapta a megyében a közrendközbiztonság védelmét. Működő intézményei a közgyülés, a kisgyülés, az önálló falusi rendfenntartás, a megyei szolgabíró, a pandúr, hajdú és huszár intézmény, az 1830-as évektől kezdve pedig a csendbiztosi rendszer. A megyei nemesi rendvédelmet a vadör, a csősz, a gátőr, a mezőőr, a bakter a foglalkozásukból eredően, jelentős mértékben támogatták. Az 1840-1890 között müködő Mezei Rendőrség intézménye elsősorban a mezőgazdasági termelési feltételeket, a terményt védte. ${ }^{17} \mathrm{~A}$ vármegyei vezetés a megyegyülések közbiztonsági helyzetről szóló döntéseiből fakadó feladatokat a települések tudomására „levelesített körözések" (proscriptiok) formájában hozta. Ezek teljesítéséröl a közgyüléseken rendszeresen beszámoltatták az alispánt, később pedig a másodalispánt és a szolgabírókat.

Ezt a fejlődést azonban jelentősen befolyásolta, gátolta, hogy a vármegye területén egy időben négyféle közigazgatási és rendvédelmi intézményrendszer müködött, amelynek kombinációi mintegy kétszáz éven keresztül egymást kiegészítve, egyik modell a másikra hatva, vagy egymást ötvözve funkcionáltak. 
A korábban leválasztott Solt- szék területéről, ahol a török hódoltság idején 1660-1690 között parasztvármegye müködött, annak intézménye, egységei és módszerei hatottak a Mezőföldön is. E formában a parasztkapitánynak volt meghatározó szerepe, lovaskapitányok, hadnagyok, tizedesek, falusi bírók: utcánként, portánként szervezték a falvak önálló rendvédelmét. A területen a lovaskapitány alárendeltségében megjelentek a hajdúk (huszárok) is. A hajdú a parasztvármegyében lehetett fegyveres állathajtó, botos legény, később vármegyei törvényhatósági ember, illetve közbiztonsági szolgálatot teljesítő egyenruházott szolga, altiszt.

Az 1704-1709 között müködött a megye közel kétharmadánál a Mezőföld egészét és Sárrétet birtokló kurucok saját intézményrendszere, a LOSONCZY Farkas István alispán által irányított kuruc vármegye. ${ }^{18}$

Ezen a területen portyázó kuruc lovas-katonák voltak a rendvédelem oszlopai. A város a kurucokkal szemben ellenségesen viselkedett, míg a falvak e rendvédelmi formában jól megszervezve, támogatóan vettek részt.

Fejér vármegye északi, északnyugati részén 1692-1704 és 1710 -1711 a nemesi vármegye intézményrendszere úgy müködött, hogy azt Győrből, némely vezetők pedig Bécsböl irányították a megyét a korábban megválasztott és elmenekült tisztikar, amely közbiztonságának alapvető felelőse, később egysége a pandúr szolgálat volt. ${ }^{19}$

Ugyanakkor a vármegye közbiztonságának mintájára — a városi lakosság elégedettségét meghatározó módon befolyásoló - úgynevezett „széles-spektrumú” rendvédelmi szervezetként müködött a Kapitányi Hivatal és alkalmi segítő szervezetei, például a vásárbíróság, az Öreg-hegyi és a külterületi csőszök, a boltörség. A „széles-spektrumú” rendvédelmet segítették elő az úgynevezett közbiztonsági megállapodások is, amelyeket a szomszédos falvakkalkötöttek. ${ }^{20}$

A nemesi vármegye működésének első szakasza az 1692 és az 1704-es évek közötti időszakra esett. Ebben az időben azonban a kurucok elfoglalták a megye mintegy kétharmadát és ott az úgynevezett „kuruc vármegyét" müködtették. Ebben az időben a nemesi vármegye csak Fejér vármegye keskeny, ÉNY-i sávjára terjedt ki. A tisztikar Győrbe költözött és onnan kísérelte meg irányítani ezt a területet. A müködés második szakaszában 1710-1711 között a nemesi vármegye ismét Fejér vármegye teljes területén érvényesülhetett. Ebben az időszakban 109 közgyülés közül 71 foglalkozott rendvédelmi témával is. ${ }^{21}$ (Lásd I.sz. melléklet)

Az 1711 után fejlődő és benépesülő megyét 1767-ben már három járásra osztották ${ }^{22}$ A megyében a mezőgazdasági és a kereskedelmi fejlődés következtében a kereskedelmi és a gazdasági központokból a XVIII. század közepére 16 település mezővárosi rangra emelkedett. A nagybirtokos nemesség mellett a megyei közéletben és a közigazgatás ellátásában jelentős szerep jutott a birtokos köznemességnek, amelynek több tagja hivatalt vállalt és a reformkor során a haladó eszmék támogatójává vált. Fejér vármegye fejlődésére jellemző volt, hogy az 1830-as évtizedben a területén egy szabad-királyi város Székesfehérvár, 17 termelési, kereskedelmi (ezen belül vásártartási joggal bíró) mezőváros, 72 falu, 15 községesített puszta és 273 major terült el. A megyében mintegy 100 ezer fö lakos élt. A vidéken élö népesség 76 \%-a mezőgazdasági munkát végzett és a XIX. századi vásárokra, valamint a Bécsi kézmüves, növény- és állatvásárokra termelt, amely alapvetően biztosította a kereskedő, a nagybirtokos jövedelmét, a kisbirtokos nemesség, sőt a falusi népesség megélhetését. A járások területi besorolását 1878. március 1.-től ismét módosították, mégpedig a Sármelléki járás elnevezését Székesfehérvári járásra változtatták és ezen felül még négy járást alakítottak ki. ${ }^{23}$ Ekkor a változásokhoz igazították a vármegyei tisztikart és a rendvédelmi intézményrendszert is. (Lásd II.sz. melléklet)

A nemesi vármegye intézményrendszerének legfontosabb jellemzöje az önkormányzatiság volt. A közrend-közbiztonság tekintetében az önkormányzatiság négy fö téma köré csoportosult.

- Gyülések (közgyülés, kisgyülés), amelyeken a nemesek a közbiztonsági kérdéseit rendszeresen megtárgyalták és a helyzetet elsősorban a közgyülési jegyzőkönyvekben és az alispáni jelentésekben dokumentáltak.

- A megyei igazságszolgáltatás, amely elvileg független és elválasztott jogág volt a közbiztonságtól. A gyakorlati kivitelezés során azonban keveredtek.

- A közbiztonság.

- A bünözés. (Lásd III.sz. melléklet)

A közbátorságra veszélyes büncselekményeket elkövető bűnözők több csoportban tipizálhatók. ${ }^{24}$

„Régi emlékeinkben, a gonosztevők lopóknak, húzavonóknak, paráznáknak, gyilkosoknak, mordályégetőknek, gyújtóknak, ünneprontónak, kóborlóknak neveztetnek, mely utóbbiak alkalmasint ugyanazok a futó-betyárokkal neveztetnek." ${ }^{25}$ Napjainkra — a XIX. század elejére — a betyár elnevezés, mint fogalom 
volt a gonosztevői kör egyik kiemelt kategóriája: „,betyár az olyan handabandázást vagy hetykélkedő önerejében elbizakodott, másokat lenéző, magát mindenekben jogosított fönek tartó, saját zajló indulatainak parancsolni nem tudó, semmit- nem tevés után is könnyen élni szerető egyén, ki ürügyet keres a másokkal való versengésre. Aki hányavetiségböl aljas tetteket végrehajt, és ha elvetemült, isteni, emberi törvényekkel dacolva, családja hírnevével mit sem törődve, egészségét és életét ok nélkül is folyvást kockáztatva korlátlanul kicsapongva él." ${ }^{26}$ A nemesi vármegye hosszú történelme során, a bűnözöi kör általában vegyes öszszetételűnek volt mondható, azaz mindig ugyanazon rétegek, a saját társadalmi, gazdasági változó környezetükből, romló helyzetükből következően váltak bünözővé, illetve a közbiztonságra veszélyes személyekké. A korszak szakirodalmában összefoglaló néven használt betyárbünözés négyféle bünözői csoportot jelentett, úgymint futóbetyárok (megugrott katonák), rablók (a legaljasabbak), tolvajok (jószágot loptak és átbélyegezték az állatokat), kapcabetyárok (minden ingóságot loptak).

\section{Fejér vármegye rendvédelme.}

A nemesi rendvédelem vármegyénként eltért egymástól, bár voltak hasonlóságok a szervezetben, a müködésben és a helyi szabályozottságban egyaránt. A közbiztonság eltérő körülményei miatt a vármegyék közötti különbségek voltak a meghatározóak. A török hódoltsági előzménnyel rendelkező nemesi vármegyék fejlődése csak később teljesedhetett ki, mint a török megszállás által nem érintett vármegyéké. A másik sajátosság a rendvédelem önkormányzati jellege volt, amelyet a HABSBURG ház uralkodói a müködés során csak kismértékben befolyásoltak, és csak rövid ideig centralizáltak. ${ }^{27}$

A centralizálásra jellemző intézkedés volt a vármegyei adminisztrátor funkció bevezetése a reformkorban 1830 körül, továbbá a titkosrendőrség, valamint a császári csendőrség bevetése, illetve a kormánybiztosi rendszer alkalmazása 1849 után a BACH-korszakban. ${ }^{28}$ További sajátosság volt, hogy a nemesi rendvédelem „követő” jellegü volt. Ez, azt is jelentette, hogy általában bünmegelőzéssel egyáltalán nem foglalkoztak, a közrend-közbiztonság javításával az eseményeket, a történteket a közgyülés tudtával „csak követték". Például a súlyosabb büncselekmények elkövetése után csak néhány nap múlva értek a helyszínre, megpróbálták a tanúkat összegyüjteni és az eseményeket rekonstruálni. Mindezek miatt intézkedéseik, csak írásbeli utasítások (proscripcióik), illetve ajánlások lehettek a falusi rendőrségek számára, az elkövetők elfogását ez csak ritka esetben eredményezte. Éppen az eredményesség vizsgálata során állapítható meg az a tény, miszerint minden a közbiztonsággal kapcsolatos intézkedés, vagy tett csak a megyehatárig szólt, azaz a vármegyei szervezetek kizárólag a vármegyehatárig voltak illetékesek, ez volt a negyedik jellemző. A vizsgált korszakban a szomszéd vármegyei szervek egymással csak igen ritka esetben müködtek együtt (az együttmüködéshez előzetesen közgyülési felhatalmazás volt szükséges). Ez a gyakorlat, akkor is igaz volt, ha a kiegyezést (1867) követően a belügyi tárca a vármegyék közötti koordinációt erőteljesen szorgalmazta. Az együttmüködés hiányát maximálisan kihasználta a betyár, a banda és a cigánybünözés, stb. Ugyanez volt az oka van annak is, hogy a bünözöi bandák, mindig a vármegyehatárok mellé (Veszprém, Somogy és Tolna megyék) települtek és az elkövetés helyét és a rejtőzködés helyét két szomszédos vármegye között rendszeresen cserélték, ezzel kizárva elfogásuk legkisebb esélyét is. Az ötödik jellemző az volt, hogy a közbiztonságért elsősorban az alispán, a másodalispán, a szolgabírók és 1867 után pedig a vármegyei csendbiztos, míg a nagy ritkán elfogott elkövetők felelősségre vonásáért a tiszti ügyész felelt.

Az önkormányzatiság lényege képezte a közgyülés elvi felelőssége. Végül az utolsó hatodik jellemzöjeként a nemesi vármegye rendvédelmének részbeni szabályozása tekinthető. Ilyen lényegi szabályozási esetek voltak 1861. december 19.-én a vármegyei tisztikar újjászervezése, vagy a főispán 1868. évi 12. pontos javaslata a közbiztonsággal kapcsolatos kiemelt intézkedésekről, vagy az 1871 után kialakított csendbiztosi kerületek, vagy a pandúrok és a hajdúk számáról, illetményeiről, járandóságaikról szóló döntések, stb.

A Fejér vármegyei rendvédelmi szervezetének lényegét, a vizsgált évszázadok során az jellemezte, hogy:

- a vármegye és Székesfehérvár közigazgatásáért is az uralkodó által kinevezett föispán felelt;

- a közbiztonsági feladatok irányítását és ellenőrzését az alispán, majd 1870 után az első és második alispán valósította meg, a közbiztonságról pedig félévente számoltak be a közgyülésnek;

- velük együttmüködésben, de nem alárendeltségükben müködtek a tiszti ügyészek;

- a rendvédelem konkrét irányításában a föszolgabíró és járásonként 2 fö szolgabíró is részt vett;

- folyamatosan mozgósította az élet- és vagyonvédelem terén a hivatásukból fakadóan tevékenykedö személyeket (vadör, halör, bakter, pályaör, út- és hídör, csősz, stb.); 
- 1766 után bevezették járásonként a strázsamester és csoportonként a káplári funkciókat, akik közvetlenül vezették a lovas, gyalogos pandúrokat, illetve hajdúkat;

- 1840 és 1890 között — a magyar Szent Korona alá tartozó területekre kiterjedően, így Fejér vármegyében is — működött a Mezőrendőrség, amely a mezőgazdasági termelés feltételeit és a terményt óvta;

- 1871 után a járásokkal azonos területen — müködtették állandó és alkalmi jelleggel — a csendbiztosi rendszert. (Fejér vármegyében a csendbiztosok szerepe, fontosságuk, alkalmazásuk nem terjedt úgy el, mint az például a Dél -Alföldi területen jellemző volt);

- a közrend egyenruhás végrehajtói állománya a vármegye és a járások között megosztott volt, az alispán közvetlen alárendeltségében csupán 4-6 fö lovas-hajdú, később megyei huszár teljesített szolgálatot, ugyanilyen felelősségi körbe illeszkedett a megyei börtönt örző pandúr alegység is;

- a vármegyei tisztikar folyamatosan követelte a falvaktól a falusi rendőrségek müködését, amelyek éjjeli őrséget, mezei örséget, tüzőrséget, vásári őrséget és úgynevezett orvos-rendőrséget müködtettek. (Lásd IV.sz. melléklet)

A falvak rendvédelme támaszkodott a nemesi vármegye rendvédelmére, annak alsó fokú végrehajtó részét képezte. A falu rendvédelmének vezetője a falu bírája, később a jegyzője volt. Fejér vármegyében a nemesi közgyülés által elöirt módon - a XVIII-XIX. században úgynevezett éjjeli rendőrség ${ }^{29}$ — valamint falvanként 1-2 bakter tevékenykedett. A bakter (éjjeli őr) vagy virrasztó, a település biztonságára, nyugalmára, a tüzvészek elhárítására vigyázó éjjeli őr. A bakterek éjjelente járták a település utcáit, rövid intő verseket mondtak és óránként kikiáltották az időt. Fegyverzetük helebárd, cifra lándzsa, vagy csak egyszerü somfabot volt. Ismert nótájuk volt a korszakban. ${ }^{30}$

A parasztvármegye ,igazi legénységét” armausoknak hívták. „Ezektől örökölték az ármás nevet a mai fokost viselő községi cselédeink, akik a kisbíró vezetése alatt a községi elöljárók által az engedetlenek ellen a végrehajtásokra használhatták. ${ }^{, 31}$ A jól megszervezett falusi rendvédelem részei voltak: az éjjeli örség, a mezei őrség, a tủzőrség, az alkalmi vásári őrség és hangsúlyozottan az orvosi rendőrség. Az utóbbi az emberi és állati járványok elleni küzdelmet, valamint a korszakos falusi tisztasági szabályokat szervezte és ellenőrizte portánként.

A vizsgált időszakban a közbátorságra veszélyes személyek több csoportot alkottak. Ilyen csoportokat képeztek az úgynevezett bandák, a cigányok és a betyárok. A vándorcigányok menetvonala eleve a nagyobb települések melletti térségeket — elsősorban a vásárok és a müvelt földterületek miatt — valamint a vármegyehatár menti területeket érintette. ${ }^{32}$

Ezeken a területen megjelentek az oláh cigányok. Jellemző bűncselekményük a rablás volt. Alapvetően vérségi alapon szerveződő cigány rablóbandák jöttek létre, mint például az Ozorai, az aranymosók, a pecsétnyomók, vagy a Lepsényi cigányok, stb. A büncselekmények elkövetésével az oláh cigányokat vádolták elsősorban, akik a vármegyébe 1700 után DK-i irányból, Dél-Erdély felöl vándoroltak be. Sátoros életmódjukat megtartva, folyamatosan követtek el lopásokat, állatlopásokat és rablásokat, vagy pecsétnyomó, metsző módszerrel „nagy tolvajlásokat”, például 1798-ban, vagy 1815-ben. Az 1780-1783-as cigányösszeírások alapján Fejér vármegyében 198 teljes cigány család tartózkodott, közülük csupán egy család élt Fehérváron. A cigány családok összlétszáma hozzávetőlegesen 1000 fö letelepedett cigány embert jelentett. Mintegy 60-100 fó cigány azonban, 8-10 stráfkocsival állandóan kóborolt és fokozott veszélyt jelentett a mezővárosok és falvak közbiztonságára. Előfordult, hogy cigányokból és a szökött katonákból szerveződő bandák telepedtek meg a megyehatáron, és együttmüködve közösen követtek el bűncselekményeket. ${ }^{33}$ Például városból hazatérő kereskedőket 1744-ben Lepsényben, majd 1876-ban Székesfehérvár határában raboltak ki. ${ }^{34}$

A vármegye kemény küzdelemben, de eredménytelenül küzdött a betyárbünözéssel. ${ }^{35}$ A betyárok búvóhelyei a Fehérvárhoz nagyon közeli Palota mezőváros határán a Bakony hegység mentén az erdő szélén terültek el, innen indultak bevetésekre, portyáik célpontja a fehérvári vásárokra menő és távozó kereskedők voltak. Emellett tevékenységüket a Duna parttal párhuzamosan húzódó évezredes hadiúton mozgó postakocsijárat megtámadására, vagy a vásárokat követő kocsmai szórakozók, vagy a kastélyok, kifosztására is kiterjesztették. A betyárok különösen veszélyes csoportjai a vegyes összetételü rabló csoportok voltak, akik kastély- vagy faluszél kifosztásokat és több alkalommal gyilkosságokat hajtottak végre. Ezek közül a legismertebbek voltak: STEINER Pinkász és bandája ${ }^{36}$ által 1857-1858-ban Csákvár, Bicske, Fehérvár környéki településeken elkövetett rabló-gyilkosságok. Hasonló súllyal estek latba a kastély- és falukifosztók. A nagyon durva esetek közül kiemelkedik 1858. január 13.-án a kajászó-szentpéteri ANDRÁSSY kastély értékei és 3000 Ft készpénz és annak tulajdonosa ANDRÁSSYNÉ született VÉGH Márietta és a szolgái ellen elkövetett rablás és kifosztás büncselekménye. A betyárbandák közül a legismertebbek voltak: az 1830-40-es 
években tevékenykedő SOBRI Jóska és bandája ${ }^{37}$ Majd az 1848-1849-es forradalom és szabadságharc leverését követő elnyomás idején, 1849 után SAVANYÚ Jóska és bandája. Mindkét betyárbanda elsősorban Veszprém és Somogy megyét fenyegette, azonban rendszeresen követtek el büncselekményeket Fejér vármegyében is. Legfőbb búvóhelyük a Palota település határában kezdődő Bakonyi erdők voltak. Támadásaik elsősorban a posta-kocsijáratok (1872 és 1873) és a fehérvári vásárra tartó, vagy onnan távozó kereskedők ellen irányultak (1874 és 1878). A nemesi vármegye közigazgatása a nyolcvanas évek első felében „megszabadult” az egyik legnyomasztóbb feladatától a közbiztonság védelmétől, azzal, hogy felállitásra kerül a Magyar Királyi Csendőrség. A katonailag szervezett központosított közbiztonsági örtestület országos kiépítésének indokai között első helyen állt a közbátorság helyreállítása és megvédése. ${ }^{38}$

\section{A Magyar Királyi Csendőrség müködése Fejér vármegyében.}

1882. január elsejével kezdődött meg — az Erdélyi Csendőrség mintája alapján — a Magyar Királyi Csendőrség országos szervezeteinek a kiépítése. ${ }^{39}$ A szervezet létrehozása ütemezve, keletről nyugat felé haladva, éves ütemezésben történt. A csendőrkerületeket több egymással szomszédos, történelmi, gazdasági, kulturális, és hasonló közbiztonsági viszonyokkal „küzdő” vármegyékben hozzák létre. ${ }^{40}$ Utolsóként alakul meg a VI. hadrendi sorszámot viselő Székesfehérvári Csendőrkerület, amely kezdetben lényegében a teljes Dunántúli területen illetékes volt. ${ }^{41}$ Létrehozásának indokairól és időpontjáról a belügyminiszter levélben értesítette a Fejér vármegye föjegyzőjét, hogy az 1881. évi. III. tc. alapján felállítják a vármegyében is a csendőr őrsöket. ${ }^{42} \mathrm{~A}$ jogszabály hatálybalépését BóNÉ Géza Fejér vármegye alispánja 1883. április 21.én hirdetményben tette közzé. ${ }^{43} \mathrm{~A}$ vármegyei hatóságok kötelesek voltak a vármegyei pandúrok közül azokat, akik csendőri szolgálat ellátására jelentkeztek és arra alkalmasak voltak, valamint a megyei pandúrok számára biztosított épületeket és felszereléseket átadni a csendőrségnek. Fejér vármegyében a törvény és az 1882. évi belügyminiszteri irányelvek alapján 14 csendőr őrsöt állítottak fel 1884 . január elsején. A „proaktív" (megelőzés-típusú) csendőri — alapvetően portya-szolgálatban — 74-87 fö gyalogcsendőr teljesített szolgálatot. Közülük egy 9 fös őrsöt - Fehérvár város felsővárosi részén, annak falusi jellegére hivatkozva - igényelt a város vezetése, amely őrs 1912 -ig müködött. ${ }^{44}$ Fejér vármegyében vidéken 13 csendőr őrsöt állítottak fel, amelynek őrsönkénti létszámát 5-6 föben határozták meg. Egy évvel később a veszprémi megyehatárhoz közeli — Polgárdi településen állítottak fel örsöt. A Magyar Királyi Csendörség Fejér vármegye őrsein szolgálatot teljesítő csendőrök a lakosság megelégedésével látták el feladatukat. Annak ellenére, hogy létszámuk közel azonos volt a megelőző önkormányzati rendfenntartókkal, teljesítményük, eredményességük a korábbi dupláját érte el.

A Magyar Királyi Csendőrség Fejér vármegyei felállítását követő évben keletkezett alispáni jelentés az 1884. évről megállapította:

„-- A közbiztonság megzavarva nem volt!

- Az állami csendőrség dicséretesen teljesítette a szolgálatát!

- A csendőrség müködése megkezdődött, a várakozásnak megfelelnek!

- Jellemzi a katonai fegyelem, a feltétlen részrehajlatlanság, a magasabb érzelmi fokozat!

- A fegyverhasználathoz a lakosság nincs hozzászokva!’45

A csendőrség közbiztonsági járőrszolgálatának eredményességét bizonyítja az 1889-es alispáni jelentés, amelynek legföbb következtetése az volt, hogy a korábbi önkormányzati rendvédelmi szervezettel szemben, a közel azonos létszámban tevékenykedő csendőrség a vármegyében közel kétszeres eredményességet ért el.

Fejér vármegyében müködő csendőrség 1884. évi megalakulásától a rendvédelem minőségi fejlődése figyelhető meg. A korábbi helyzetet és a fejlődést mutatja a Székesfehérvár szabad királyi-, majd törvényhatósági jogú városban müködő rendvédelmi szervezettípusok 1800-1867 közötti, valamint 1867 és 1900 közötti müködésének a hatékonyságát.

Tanulmányomban nem foglalkoztam a különleges időszakokban — például az 1803-as nemesi felkelés idején, vagy a reformkorban, illetve az 1848-1849-es forradalom és szabadságharc alatt — müködő polgári önkéntes rendvédelmi szervezetekkel, mint a polgárőrség vagy a nemzetőrség, bár ezen időszakok rendvédelmi testületeit több kutató hangsúlyozottan kezeli. ${ }^{46}$

A tanulmányomban vázolt alrendszerek, mint a vármegyei önkormányzati rendészet, évszázadokon át alkotta Fejér vármegyében is a közrend-közbiztonság alapját. Ezt váltotta fel Fejér vármegyében 1884-ben — a városok területének kivételével — a Magyar Királyi Csendőrség alakulatainak rendvédelmi tevékenysége. 
Álláspontom szerint — annak ellenére, hogy a különleges időszakokban működő — speciális szervezetek csak ideiglenes szerepet játszottak a megyei közrendvédelem fejlödésének folyamatában a meghatározó és stabil rendvédelmet Fejér vármegyében a nemesi rendvédelmi struktúra alkotta, amely azonban önmagában is folyamatos fejlődésen ment keresztül.

\section{$\frac{\text { Jegyzetek: }}{1 . \text { Az egyil }}$}

Az egyik a megye 2/3-ad részét, a Dunántúli oldalon, amely a nagyobb földrajzi egységét érintette a Kelet-Dunántúlon (a Bakony és a Vértes hegység lejtöitől, a Sárrét mocsárvilágán át a Mezöföldig) húzódott, amíg a másik a Duna-túlsó oldalán, a Duna-Tisza közén az úgynevezett Solti szék területét és a Csepel szigeti ispánság területét érintette. Nemcsak állami szervezésében, gazdaságában volt kettős a vármegye szervezése, hanem egyházi, vallási szempontból is kétközpontúnak számított. Amíg a Dunántúli terület a Székesfehérvári káptalan, addig a másik, Duna-Tisza közi, Solti szék vallási központját jelentő Kalocsai érsekség területét jelentette.

2. $1596 /$ LII.tc.

${ }^{3 .}$ Az elsőhöz a Vértesaljaihoz tartozott: Mór, Bodajk, Csókakő vára, Csákberény, Zámoly, Csákvár, Lovasberény, Pátka, Pákozd, Sukoró, Nadap, Pázmánd, Vereb, Vértesacsa, Felcsút, Alcsút, Tabajd, Szentpéter, Ráckeresztúr, Tordas, Gyuró, Etyek, Bicske, Mány, Sóskút, Tárnok, Érd, Százhalom, Ercsi. A másodikhoz, azaz a Sárrét járáshoz tartozott: Ladány, Szt.Mihály, Kiskeszi, Battyán, Csíkvár, Füle, Polgárdi, Tác, Soponya, Káloz, Egres, Vajta, Cece, Sárkeresztúr, Aba, Seregélyes, Pentele, Adony, Almás, Perkáta, Moha, Szentgyörgy, Csór, Inota, Keresztes, Csúrgó.

4. Perkátán a XIII. században jelentős számban telepedtek meg a kunok. Árpád kori falut és temetőt tártak fel 2010-2011ben. ,A legnagyobb kun szálláshely volt a Dunántúlon.

Kunok és besenyők Fejér Megyében.

${ }^{{ }^{5}}$ Fejér vármegye szomszédjai É-ról Komárom-Esztergom, Pest-Pilis-Solt, Ny-ról Veszprém, DNy-ról Somogy és DK-röl Tolna vármegyék, majd 1596-tól K-ről a Duna folyó határolták. A török hódoltság kezdetéig Fejér vármegyét a Sármelléki, a Csákvári járásokra és a Solti székre tagolták.

6. BENCZÉDI

7. SIKLÓSI

8. HEGYI

9. NÉMETH 51.p.

10. VASS

${ }^{11}$ Ezzel szemben Mátyás király korában Fejér vármegyében 7 nagyobb helység és 422 falu volt.

12.ERDÖs: Fejér vármegye újjászervezése 1692-1693.

${ }^{13}$ Németeket Tárnok, Tordas, Etyek, Acsa, Mór, Isztimér, Szár településekre, szlovákokat Tárnok, Tordas falvakra, rácokat Fehérvár városba, és a Duna mellékére, valamint Alsószintiván, Perkáta, Sóskút és Ráckeresztúr falvakaba. 1690-ben bosnyákokat és szerbeket pedig Bicskére és környékére is telepítettek.

BENCSIK: I.köt. Fejér vármegye. 185-192.p.

14.'́gy többek között: gróf BATTYÁNYI Ádám Polgárdi, Battyán, Bicske és Mór környékén, galántai gróf EsZTERHÁZY Ferenc Sárosd és Jakabszállás, gróf EsZTERHÁZY Antal Csákvár, Magyaralmás, stb. Már 1650-ben ZICHY István Palota és a mellette lévő községek, Csókakő, Adony, Soponya, Káloz, Vajta, stb. A bécsi udvar hadiszállitója báró HochBuRG Mór, Csókakő, Csákberény, Keresztes, Csúrgó, Zámoly és Csákberény falvakat. Gróf HEISTER generális Lovasberény, Rácz-keresztúr, Nadap és Börgönd településeket. A fentieken felül MesZLÉNYI János Velence, Bodmér, Cece, a várkonyi AMADE család birtokolta Moha-Iszkaszentgyörgy falvakat. Óriási földterülethez, uradalmakhoz jutottak a Katolikus Egyház Etyek, Vál, Vereb, Sukoró, Pákozd, Gyuró, Pázmánd, Acsa településeken, míg a Györi Jezsuita rendház Perkátát, a Ciszterciek Nagyvenyim, Előszállás és Nagykarácsony falvakat mondhatta magáénak. Mindez teljesen átrendezte a török hódoltság elötti tulajdoni viszonyokat.

FARKAS: Nagybirtokosok Fejér megyében a török kiüzése után.

15.ERDÖs: Fejér vármegye újjászervezése 1692-1693. : op.cit.

16.ZSOLDOS - NEUMNAN

17. $1840 /$ IX.tc.

18. Az úgynevezett kuruc vármegye központjai Ladányban és Szentmihályon működtek.

${ }^{19}$ A pandúr a XIX. századi rendfenntartó fegyveres alakulat tagja.

Én „A pandúrságot még Árpád fejedelmünk korabeli ősi intézményének nyilvánítom.” Már a királyi vármegyében a várispán (később föispán) a fejedelem nevében igazságot szolgáltatni, a hadban a harcosokat zászlója alatt vezetni, és a közrendre felügyelni lettek kötelességei.” O’svÁTH szerint: „a pandúrság ösi, magyar intézmény, amelynek tagjai katonák voltak és a régi koroktól kezdve pandúr volt a magyar rendőr neve."

O’svátн: Közbiztonságunk múltja és pandúr korom emlékei (a régi magyar élet feltüntetésével).

A szerző teljes munkássága alatt tiltakozott az ellen, hogy ezt az ősi elnevezést akármelyik zsandár, polizei, rendör, vagy csendőrré magyarított névre cseréljék fel. Más megközelítésében, életútja későbbi írásaiban hajdúként, vagy huszárként ${ }^{1}$ is szerepelnek. A hajdúk (gyalog- és lovas) az XVI. század végén és a XVII. század elején a RÁKóczI Szabadságharcot, illetve a törökök kiüzését követően a katonáskodás mellett kaptak fokozatosan rendvédelmi szerepet a Dunántúlon is.

A pandúr (persecutort, azaz üldözőt jelentett), aki a nemesi vármegye rendfenntartó fegyverese volt, és amely szervezet általában a nemesi vármegyéböl származik. A közbiztonság közvetlen feladatát végzök öltözete a vármegye sárga-zöld színét viselte, amely a hajdúk, a huszárok (a vármegye szívesen alkalmazott a kiszolgált húszárokat közrendvédelmi feladatokra), 
pandúrok, kerülök öltözékén, kocsikon, a pecsétek zsinórjain, a katonák tarsolyain is megjelent. A XIX. századra a vármegyeháza és a vármegye tulajdonában lévő házakat is ez a címer díszítette.

DARKÓ ; TÓTH

${ }^{20}$ A ,,széles-spektrumú” rendvédelem magában foglalta a közbiztonság általános védelmét, a mező- és erdő őrségeket, a tüzőrségeket, továbbá az úgynevezett vízirendészetet és egészségügyi rendészeti teendőket is.

${ }^{21}$ FARKAS: A vármegyei regeszták minősítése.

22.A járások székhelyei voltak: Sármellék, Csákvár, Bicske.

${ }^{23 .}$ A négy új járás székhelyei voltak: Mór, Sárbogárd, Adony és Vál.

${ }^{24}$ FARKAS - MÓRA

${ }^{25}$ O'SVÁTH: Közbiztonságunk állapota hajdan és most különös tekintettel Bihar megyére.

26. O’svÁTH: Pandúr élmények.

${ }^{27}$ Ilyen centralizációs törekvés közé tartozott a katonai közigazgatás rendszerének alkalmazása 1688-1692 között, az ural-

kodó II. József közigazgatási, centralizálási, vagy átszervezési intézkedései, és kísérletei az 1700-as évek második felében.

28.PARÁDI: A magyar rendvédelem története. 39-67.p.

29.ERDÖs: Alispáni jelentések.

30. Ismert nótájuk volt:

„Hallja minden háznak ura,

Tízet ütött most az óra

Tüzre, vízre vigyázzatok

Hogy károkat ne valljatok"

${ }^{31}$ O'sVÁTH: A megyei csendbiztosok emlékiratai.

32. FARKAS - MÓRA: op.cit.

${ }^{33}$ HEICZINGER

${ }^{34}$ ERDŐs: Alispáni jelentések. : op.cit.

${ }^{35}$ FARKAS - MÓRA: op.cit. 63.p., 64-67.p. , 68-69.p. , 70-71.p.

${ }^{36}$.STEINER Pinkász bandáját 1858 kora tavaszán a megyei hatóságok csellel elfogták és a bandájával együtt 1858. március 19.-én Fehérvár föterén nyilvánosan kivégezték. Az eset azért és érdekes, mert ekkor kellett a Fehérvári Kapitányi Hivatalnak a lincselést követelö tömeggel szemben tömegoszlatást végrehajtania.

37. A banda tagjai voltak: MilfaJT Ferkó alvezér, MÓGOR Jancsi, Zsidó Józsi, Holics Gyuri, KIRÁly Jancsi, LAKAT Miska, Kiss Jancsi.

38.1881/II.tc. ; 1881/III.tc.

39.REKTOR: 68-95.p. ; PARÁDI: A polgári magyar állam első központosított közbiztonsági szervezete a Magyar Királyi Csendőrség. ; PARÁDI: A csendőrség magyarországi története. ; SzAKÁLY: A Magyar Királyi Csendőrség az első központosított közbiztonsági őrtestület.

40. CSAPÓ: 20-52.p. ; PARÁDI: A Magyar Királyi Csendőrség megalakulása és müködése 1881-1918. ; PARÁDI: A Magyar Királyi Csendőrség szervezete. ; SzAKÁLY: A Magyar Királyi Csendőrség 1919-1941.

${ }^{41}$ FORRÓ: A székesfehérvári csendőrkerület kapcsolata a közigazgatással. ; FoRRÓ: A székesfehérvári csendőrkerület küzdelme Fejér vármegye közbiztonságáért 1884-1945.

42.FML 8733/1883. A BM 66 121.sz. levele Fejér vármegye Főjegyzőjéhez.

${ }^{43}$ Kunok és besenyők Fejér Megyében.

44. $1882 /$ X.tc.

${ }^{45}$.ERDÖs: Alispáni jelentések. : op.cit.

${ }^{46}$ MAGONY

A jegyzetekben alkalmazott röviditések:

\section{MONOGRÁFIÁK}

BENCZÉDI

BENCSIK

CSAPÓ

DARKÓ

FARKAS - MÓRA

MAGONY

O’SVÁTH

PARÁDI: A magyar rendvédelem története.
BENCZÉDI László: Rendiség, abszolutizmus és centralizáció a XVII. század végi Magyarországon (1664-1685). Budapest, 1980, Akadémiai Kiadó. 180 p. HU-ISBN 96305 2326 4. /Értekezések a történeti tudományok köréböl, 91./ HU-ISSN 0071-1233.

- Bencsik Gábor: Vármegyék könyve. Milleniumi körkép Magyarországról. Budapest, 2008, Magyar Mercurius. 304 p. HU-ISBN 9789638646996.

Csapó Csaba: A Magyar Királyi Csendörség története 1881-1914. Pécs, 1999, Pro Pannónia Kiadói Alapítvány. 186 p. HU-ISBN 963907940 5. /Pannon könyvek./ HU-ISSN 0237-4277.

DARKó Jenő: A magyar huszárság eredete. Máriabesenyö-Gödöllö, 2010, Attraktor. 106 p. HU-ISBN 978963985745 2. /Studia militaria Hungarica, 6./ HU-ISSN 1787-6796.

FARKAS Gábor - K. MóRA Magda: Fejér megye múltja irott emlékekben. Székesfehérvár, 1962, Fejér Megyei Tanács Végrehajtó Bizottság Müvelődési Osztály. 156 p.

- MAGONY István: Székesfehérvár város nemzetörsége 1848. Székesfehérvár, 1898, MTA.

- O'svÁTH Pál: Közbiztonságunk múltja és pandúr korom emlékei (a régi magyar élet feltüntetésével). Budapest, 1905, s. n.

PARÁDI József: A magyar rendvédelem története. Budapest, 1996², Osiris. 367 p. HU-ISBN 9630479583. 
REKTOR

ZSOLDOS - NEUMNAN

\section{TANULMÁNYOK}

ERDÖs: Alispáni jelentések.

ERDŐs: Fejér vármegye újjászervezése 1692-1693.

FARKAS: Nagybirtokosok Fejér megyében a török kiüzése után.

FORRÓ: A székesfehérvári csendörkerület kapcsolata a közigazgatással.

FORRÓ: A székesfehérvári csendőrkerület küzdelme Fejér vármegye közbiztonságáért 1884-1945.

HEGYI

HEICZINGER

NÉMETH

PARÁDI: A polgári magyar állam első központosított közbiztonsági szervezete a Magyar Királyi Csendőrség.

PARÁDI: A Magyar Királyi Csendőrség megalakulása és müködése 1881-1918.

PARÁDI: A csendőrség magyarországi története.
Rektor Béla: A Magyar Királyi Csendörség oknyomozó története. Cleveland, OHIO, USA, 1980, Árpád Könyvkiadó Vállalat. 552 p. USA-ISBN 0-934214-01-8.

Zsoldos Attila — NeumanN Tibor: Székesfehérvár középkori kiváltságai. Székesfehérvár, 2010, Székesfehérvár Megyei Jogú Város Levéltára. 143 p. HU-ISBN 97896308 02192 /Közlemények Székesfehérvár történetéből./ HU-ISSN 1586-6998.

ERDÖs Ferenc: Alispáni jelentések. In ERDÖs Ferenc: (szerk.): Fejér megyei történeti évkönyv 1998. Székesfehérvár, 1998, Fejér megyei Levéltár. /Fejér megyei Történeti Évkönyv, 24./ HU-ISSN 0301-7532

ERDÖs Ferenc: Fejér vármegye újjászervezése 1692-1693. 63-68.p. In ERDŐs Ferenc (szerk.): Fejér megyei Történeti Évkönyv 1989. Székesfehérvár, 1989, Fejér megyei Levéltár. /Fejér megyei Történeti Évkönyv, 19./ HU-ISSN 0301-7532

FARKAS Gábor: Nagybirtokosok Fejér megyében a török kiüzése után. 171175.p. In FARKAS Gábor: (szerk.): Fejér megyei Történeti Évkönyv. Székesfehérvár, 1971, Székesfehérvári Megyei Tanács Művelődési Osztály. /Fejér megyei Történeti Évkönyv, 5./ HU-ISSN 0301-7532

FORRÓ János: A székesfehérvári csendőrkerület kapcsolata a közigazgatással. Rendvédelem-történeti Füzetek (Acta Historiae Preasidii Ordinis), X.évf. (2000) 12.sz. 58-61.p. HU-ISSN 1216-6774.A tanulmány korábbi változata 1999 október 6.-án Budapesten hangzott el a Szemere Bertalan Magyar Rendvédelem-történeti Tudományos Társaság által szervezett rendvédelem-történeti tudományos konferenciasorozatnak „A közigazgatás a véderő és a rendvédelem kapcsolatának változásai a polgári magyar állam idöszakában” címü XII. konferenciáján. A publikált tanulmány az előadás javított, bővített és átdolgozott változata.

FORRó János: A székesfehérvári csendőrkerület küzdelme Fejér vármegye közbiztonságáért 1884-1945. Rendvédelem-történeti Füzetek (Acta Historiae Preasidii Ordinis), XXI.évf. (2011) 24.sz. 32-72.p. HU-ISSN 1216-6774. A tanulmány korábbi változata 2009. december 3.-án Budapesten hangzott el a Szemere Bertalan Magyar Rendvédelemtörténeti Tudományos Társaság által szervezett rendvédelem-történeti tudományos konferenciasorozatnak ,A csendörség Ausztria-Magyarországon, illetve Ausztriában és Magyarországon 1849-2005” címü XXIV. konferenciáján. A publikált tanulmány az elöadás javított, bővített és átdolgozott változata.

HEGYI Klára: A török közigazgatás és a magyar városi autonómia. 85-97.p. In FARKAS Gábor (szerk.): Fejér megyei Történeti Évkönyv 1977. Székesfehérvár, 1977, Fejér Megyei Tanács Művelődési Osztály. /Fejér megyei Történeti Évkönyv, 3./ HU-ISSN 0301-7532

HEICZINGER János: Fejezetek a cigánykérdés alakulásáról. In FARKAS Gábor (szerk.): Fejér megyei Történeti Évkönyv 1978. Székesfehérvár, 1978, Fejér Megyei Tanács Müvelödési Osztály. /Fejér megyei Történeti Évkönyv, 12./ HU-ISSN 0301-7532

NÉMETH László: A székesfehérvári egyházmegye kialakulása (1688-1777). In FARKAS Gábor (szerk.): Fejér megyei Történeti Évkönyv 1979. Székesfehérvár, 1979, Fejér Megyei Tanács Művelődési Osztály. /Fejér megyei Történeti Évkönyv, 4./ HU-ISSN 0301-7532

PARÁDI József: A polgári magyar állam első központosított közbiztonsági szervezete a Magyar Királyi Csendőrség. Belügyi Szemle, XXXVII.évf. (1989) 2.sz. 35-40.p. HUISSN 0133-6738.

PARÁDI József: A Magyar Királyi Csendőrség megalakulása és működése 18811918. Rendvédelem-történeti Füzetek (Acta Historiae Preasidii Ordinis), HU-ISSN 1216-6774. VII.évf. (1997) 8.sz. 78-83.p. HU-ISSN 1216-6774. A tanulmány korábbi változata 1996 október 29.-én Budapesten hangzott el a Szemere Bertalan Magyar Rendvédelem-történeti Tudományos Társaság által szervezett rendvédelem-történeti tudományos konferenciasorozatnak „A napóleoni közbiztonsági őrtestület útja Párizstól - Itálián és Ausztrián keresztül - Budapestig." című VIII. konferenciáján. A publikált tanulmány az előadás javított, bővített és átdolgozott változata

PARÁDI József: A csendőrség magyarországi története. Rendvédelem-történeti Füzetek (Acta Historiae Preasidii Ordinis), XVI.évf. (2009) 19.sz. 63-87.p. HU-ISSN 12166774. A tanulmány korábbi változata 2005. október 6.-án Budapesten hangzott el a Szemere Bertalan Magyar Rendvédelem-történeti Tudományos Társaság által szervezett rendvédelem-történeti tudományos konferenciasorozatnak „Másfél évtized nemzeti rendvédelem-történetünk kutatásának szolgálatában" címü XIX. konferenciáján. A publikált tanulmány az előadás javított, bővített és átdolgozott változata. 
PARÁDI: A Magyar Királyi Csendörség szervezete.

SIKLÓSI

SZAKÁLY: A Magyar Királyi Csendőrség az első központosított közbiztonsági őrtestület.

SZAKÁly: A Magyar Királyi Csendőrség 1919-1941.

То́тн

VASS

FARKAS: Vármegyei regeszták minősítése.

\section{CIKKEK}

O’svÁTH: Közbiztonságunk állapota hajdan és most különös tekintettel Bihar megyére.

O’sváth: Pandúr élmények.

O'sváth: A megyei csendbiztosok emlékiratai.

Kunok és besenyők Fejér Megyében.
PARÁDI József: A Magyar Királyi Csendőrség szervezete. Rendvédelemtörténeti Füzetek (Acta Historiae Preasidii Ordinis), XXI.évf. (2011) 24.sz. 8090.p. HU-ISSN 1216-6774. A tanulmány korábbi változata 2009. december 3.-án Budapesten hangzott el a Szemere Bertalan Magyar Rendvédelem-történeti Tudományos Társaság által szervezett rendvédelem-történeti tudományos konferenciasorozatnak „Csendőrség Ausztria-Magyarországon, illetve Ausztriában és Magyarországon 1849-2005” című XXIV. konferenciáján. A publikált tanulmány az előadás javított, bővített és átdolgozott változata.

SIKLÓsı Gyula: A török hódoltság emlékei Székesfehérvárott. In ERDös Ferenc (szerk.): Fejér megyei Történeti Évkönyv 1989. Székesfehérvár, 1989, Fejér Megyei Levéltár. /Fejér megyei Történeti Évkönyv, 19./ HU-ISSN 0301-7532

SzAKÁLy Sándor: A Magyar Királyi Csendőrség az első központosított közbiztonsági örtestület. Rendvédelem-történeti Füzetek (Acta Historiae Preasidii Ordinis), HU-ISSN 1216-6774. III.évf. (1993) 4.sz. 51-58.p. A tanulmány korábbi változata 1992. szeptember 29.-én Budapesten hangzott el a Szemere Bertalan Magyar Rendvédelem-történeti Tudományos Társaság által szervezett rendvédelem-történeti tudományos konferenciasorozatnak „A dualista Magyarország rendvédelme" címü IV. konferenciáján. A publikált tanulmány az előadás javított, bővített és átdolgozott változata.

SZAKÁLY Sándor: A Magyar Királyi Csendőrség 1919-1941. Rendvédelemtörténeti Füzetek (Acta Historiae Preasidii Ordinis), HU-ISSN 1216-6774. VII.évf. (1997) 8.sz. 122-129.p. A tanulmány korábbi változata 1996 október 29.én Budapesten hangzott el a Szemere Bertalan Magyar Rendvédelem-történeti Tudományos Társaság által szervezett rendvédelem-történeti tudományos konferenciasorozatnak „A napóleoni közbiztonsági örtestület útja Párizstól - Itálián és Ausztrián keresztül - Budapestig. " címü VIII. konferenciáján. A publikált tanulmány az előadás javított, bővített és átdolgozott változata.

Tо́тн Zoltán: A huszárok eredetéröl. Hadtörténelmi Közlemények, XLVII.évf (1935) 129-196.p. HU-ISSN 0017-6540.

VASS Előd: Források a székesfehérvári szandzsák történetéhez. 69-90.p. In FARKAS Gábor (szerk.): Fejér megyei Történeti Évkönyv 1973. Székesfehérvár, 1973, Fejér Megyei Tanács Mủvelődési Osztály. /Fejér Megyei Történeti Évkönyv 1973, 7./ HUISSN 0301-7532

FARKAS Gábor: A vármegyei regeszták minősítése 1692-1704 és 1710-1711 évek között. In FARKAS Gábor (szerk.): Fejér megyei történeti évkönyv. Székesfehérvár, 1997, Fejér Megyei Tanács Művelődési Osztály. /Fejér megyei Történeti Évkönyv, 28./ HU-ISSN 0301-7532

O'svÁTH Pál: Közbiztonságunk állapota hajdan és most különös tekintettel Bihar megyére. Bihar, XII.évf. (1867) 173.sz. november 9. 1.p. , 174.sz. november 11. 2-3.p., 175.sz. november 12. 1-2.p.

O’svÁTH Pál: Pandúr élmények. In BAKOS Gábor (szerk.): Első magyar országos rendöri. Zsebnaptár az 1872-ik szököévre. Budapest, 1871, s.a. 35-50. p.

O’svÁth Pál: A megyei csendbiztosok emlékiratai. Bihar, XVIII.évf. (1882) 291.sz. december 20. 2.p.

Kunok és besenyők Fejér Megyében. Fejér Megyei Hirlap, LVII.évf. (1999) január 23. 3.p.

\section{LEVÉL- IRAT- és DOKUMENTUMTÁRAK \\ FML \\ FML = Fejér Megyei Levéltár}

\section{JOGSZABÁLYOK}

1596/LII.tc.

1840/IX.tc.

1881/II.tc.

1881/III.tc.

1882/X.tc.

Mellékletek jegyzéke:

I.sz. melléklet

A Fejér vármegyei tisztikar értékelése a közbiztonságról. II.sz. melléklet

Fejér vármegye lakossága a XVIII-XIX. században.
1596/LII.tc. a Solti - szék elcsatolása Fejér vármegyétől.

1840/IX.tc. a mezei rendőrségről.

1881/II.tc. a csendőrségi legénység állományának kiegészítéséröl.

1881/III.tc. a közbiztonsági szolgálat szervezéséről.

1882/X.tc. a Magyar Királyi Csendőrség által, a törvényhatósági joggal felruházott városok kül- és belterületein való teljesítendőkről.

\author{
III.sz. melléklet \\ Fejér vármegyében jellemző büncselekmények XVIII-XIX. században \\ IV.sz. melléklet
}

Fejér vármegye falusi rendvédelmének a részei a XVIII-XIX. században. 
A Fejér vármegyei tisztikar értékelése a közbiztonságról.

\begin{tabular}{|c|c|c|c|}
\hline Évek & Nemesi közgyúlés & Nemesi kisgyúlés & Összzesen: \\
\hline $1692-1704$ & 74 & 16 & 90 \\
\hline 1710-1711 & 3 & 16 & 19 \\
\hline esetek & 77 & 32 & 109 \\
\hline minősítés & $\begin{array}{l}43 \text { hiányosság } \\
12 \text { eredmény }\end{array}$ & $\begin{array}{l}28 \text { hiányosság } \\
11 \text { eredmény }\end{array}$ & $\begin{array}{l}71 \text { hiányosság } \\
23 \text { eredmény }\end{array}$ \\
\hline
\end{tabular}

Forrás ! FARKAS Gábor: A vármegyei regeszták minősítése 1692-1704 és 1710-1711 évek között. In FARKAS Gábor (szerk.): Fejér megyei történeti évkönyv. Székesfehérvár, Székesfehérvár, 1997, Fejér Megyei tanács Művelődési Osztály. /Fejér megyei Történeti Évkönyv, 28./ HU-ISSN 0301-7532.

II.sz. melléklet

Fejér vármegye lakossága a XVIII-XIX. században.

\begin{tabular}{|cl|}
\hline Évek & lakosságszám \\
\hline 1700 -as évek második felében & 107.031 fó \\
\hline 1830 & 166.368 fö́ \\
\hline 1850 & 158.266 fö \\
\hline 1869 & 196.234 fó \\
\hline
\end{tabular}

Forrás ! FARKAS Gábor: A vármegyei regeszták minősítése 1692-1704 és 1710-1711 évek között. In FARKAS Gábor (szerk.): Fejér megyei történeti évkönyv. Székesfehérvár, Székesfehérvár, 1997, Fejér Megyei tanács Művelődési Osztály. /Fejér megyei Történeti Évkönyv, 28./ HU-ISSN 0301-7532.

Fejér vármegyében jellemzö büncselekmények a XVIII-XIX. században

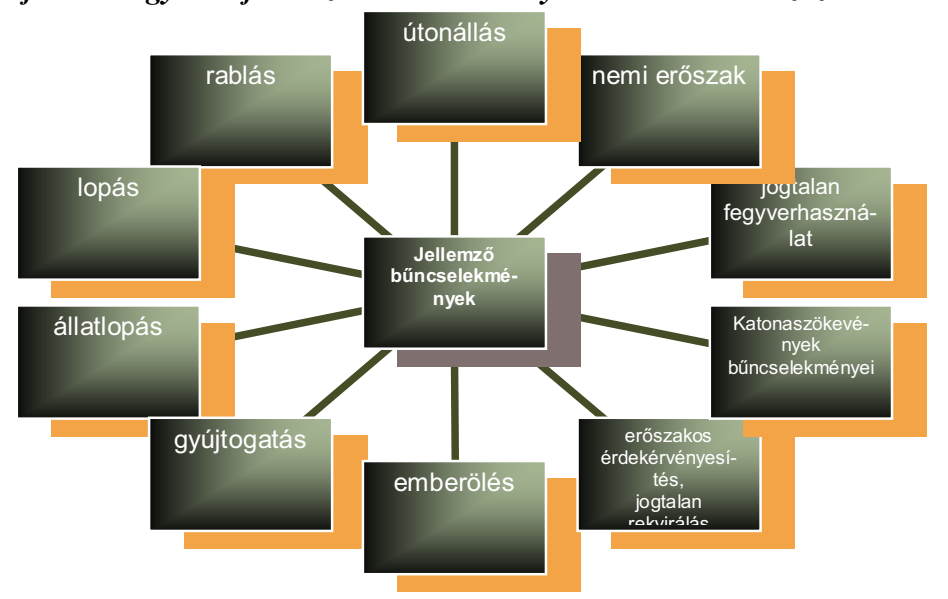

Fejér vármegye falusi rendvédelmének a részei a XVIII-XIX. században.

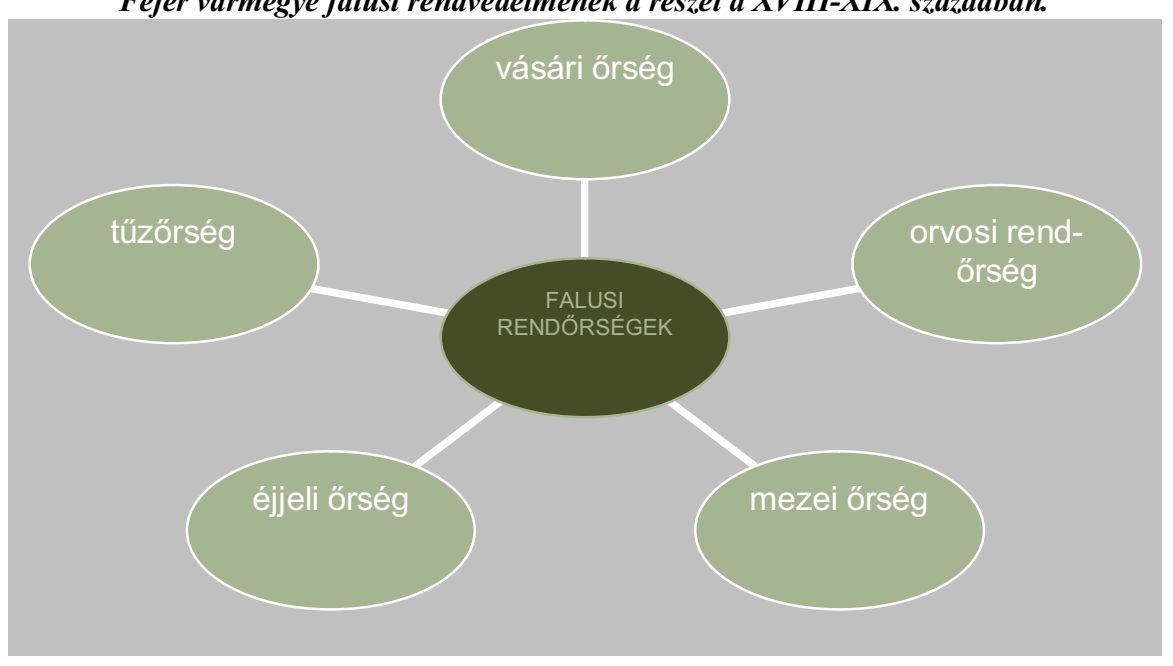

